\title{
АКТУАЛЬНІ ПИТАННЯ ПРОЄКТУ ЗАКОНУ УКРАЇНИ «ПРО СИСТЕМУ ГРОМАДСЬКОГО ЗДОРОВ'Я»
}

\author{
Тернопільський національний медичний університет \\ імені І. Я. Горбачевського МОЗ України, м. Тернопіль, Україна
}

Мета: показати актуальні питання громадського здоров'я, проголошені в проєкті Закону України «Про систему громадського здоров'я», та можливості їх реалізації.

Матеріали і методи. Використовуючи метод системного аналізу, проведено вивчення найактуальніших завдань системи громадського здоров'я у даному законопроєкті.

Результати. Даний законопроєкт орієнтований на стратегічний план розвитку громадського здоров'я, має бути консолідованим законом на кшталт Основ законодавства чи Кодексу. У ньому повинна бути чітко виписана виконавча структура, їі місце у владних органах, співіснування з ними, функціональна підпорядкованість тощо.

У даному законопроєкті вводиться нова структура - уповноважений орган у ссрері громадського здоров'я, який розглядають як «центральний орган виконавчої влади, що реалізує державну політику в сфері громадського здоров'я та санітарно-епідемічного благополуччя, у тому числі щодо організації та здійснення державного контролю, в порядку визначеному законом, за дотриманням вимог санітарного законодавства у сферах господарської діяльності, які можуть становити ризик для санітарно-епідемічного благополуччя». У цьому законопроєкті не чітко визначено місце даного органу у виконавчій структурі влади, а отже унеможливлює його співфункціонування ні в плані розподілу праці, ні в плані фрінансування.

Декларативні стратегічні тези мають мати чітко визначене фрінансування зі зазначеними джерелами поступлень та співвідноситись із фрінансовими можливостями.

Питання вакцинації на сьогодні має ознаки юридичної колізії та потребує збалансування між правами особи та інтересами громади.

Питання громадського здоров'я повинно вирішуватись консолідованими силами суспільства і узгодженими діями виконавчої вертикалі влади. Пропаганда здоров'я і профрілактика захворювань повинні бути пріоритетним напрямком державної політики у сорері охорони здоров'я.

Висновки. Безперечно, що галузь громадського здоров'я потребує вагомого законодавчого підґрунтя, яке має бути достатньо виважене, орієнтоване на інтереси як громади, так і окремого громадянина і не викликати настороги з боку населення.

КЛЮЧОВІ СЛОВА: громадське здоров'я; законопроєкт; вакцинація; безпека життєдіяльності.

В Україні на сьогодні немає закону, який регулює сореру власне громадського здоров'я, проте $€$ Закон України «Про забезпечення санітарного та епідемічного благополуччя населення» (Відомості Верховної Ради України (ВВР), 1994, № 27, ст. 218) [3]. Потреба у створенні законодавчої бази громадського здоров'я зумовлена насамперед необхідністю становлення та стратегічного проєктування системи збереження здоров'я та просрілактики захворюваності.

Мета роботи: показати актуальні питання громадського здоров'я, проголошені в проєкті Закону України «Про систему громадського здоров'я», та можливості їх реалізації.

Матеріали і методи. Використовуючи метод системного аналізу, проведено вивчення найактуальніших завдань системи громадського здоров'я у даному законопроєкті.

Результати дослідження та їх обговорення. Перше, на чому необхідно закцентувати увагу -

(c) О. Н. Литвинова, Л. П. Запорожан, К. Є. Юріїв, 2020 це на тому, що закон є нормативно-правовим актом, ухваленим в особливому порядку вищим представницьким органом держави або безпосереднім волевиявленням народу (референдум), який регулює найбільш важливі суспільні відносини, виражає волю (інтереси) більшості населення та має вищу юридичну силу. У даному випадку має регулювати суспільні відносини у напрямку збереження здоров'я населення та запобігання захворюваності.

Також закон повинен містити норми права, яких раніше в правовій системі не було. У даному законопроєкті є велика частка позицій, які вже відображені в інших законодавчих документах, про що йтиметься далі.

У вступі до даного законопроєкту йдеться майже буквально про те ж, що і у вступі до Закону України «Про забезпечення санітарного та епідемічного благополуччя населення» [3], різниця полягає лише у тому, що вставлено поняття «громадське здоров'я», а фрразу: «встановлює 
порядок організації державної санітарно-епідеміологічної служби і здійснення державного санітарно-епідеміологічного нагляду в Україні» замінено на: «встановлює правові та організаційні засади здійснення державного нагляду (контролю) у сорерах господарської діяльності, які можуть становити ризик для санітарно-епідемічного благополуччя» [7]. Дана задекларована позиція вимагає створення додаткового нормативного акта про структуру, яка здійснюватиме такий державний нагляд, та рівні підпорядкування у ній. Потрібно чітко розмежувати функції Центру громадського здоров'я, Держпродспоживслужби, МОЗ України та численних інших державних органів, які здійснюють регулювання та нагляд за чинниками довкілля, які впливають на здоров'я.

У статті 1 першого розділу запропонованого законопроєкту пропонуються визначення основних термінів і понять, що вживатимуться у даному матеріалі. I тут знову варто відзначити, що, на жаль, однакові терміни та поняття трактуються по-різному і в різних законах, зокрема схожі визначення $є$ як у даному законопроєкті, так і в Законі України «Про захист населення від інфрекційних хвороб» від 06.04.2000 р. № 1645-III [5], та в уже згаданому Законі України «Про забезпечення санітарного та епідемічного благополуччя населення» [3].

Наведемо лише один приклад. Так дублюється визначення «благополучна епідемічна ситуація» в даному документі та в Законі України «Про захист населення від інфекційних хвороб» [5]. А от визначення епідемії у цих документах різне: «епідемія - це перевищення звичайного рівня захворюваності та поширеності певної хвороби серед населення на певній території за короткий проміжок часу за критеріями, характерними для цієї хвороби, які встановлені центральним органом виконавчої влади, що забезпечує фрормування та реалізує державну політику в сорері охорони здоров'я» - це в законопроєкті, а в Законі України «Про захист населення від інфекційних хвороб»«епідемія - масове поширення інфекційної хвороби серед населення відповідної території за короткий проміжок часу», тоді, як «рівень захворюваності та поширеності хвороб населення на певній території у визначений час - це епідемічний стан» у даній редакції. Таке змішування і варіація редакції понять у трьох документах недопустиме з юридичної позиції, а на практиці призведе до дисбалансу функціональних співвідносин між структурами, які ними користуватимуться.

Певний інтерес викликає поняття «єдине здоров'я», яке автори законопроєкту подають як всеохоплююче поняття ставлення до здоров'я і трактують як «міжсекторальний підхід до роз- робки та впровадження програм, політики, законодавства та досліджень, в рамках яких взаємодіють кілька секторів, таких як медицина, охорона здоров'я людини (громадське здоров'я), медицина праці, ветеринарна медицина, безпечність продуктів харчування, екологія та природне середовище, з метою забезпечення санітарно-епідемічного благополуччя та здоров'я населення». У даному документі до поняття «єдине здоров'я» (One Health), стратегія якого розроблена та реалізується Організацією з сільського господарства та продовольства (ФАО), Міжнародним епізоотичним бюро (МЕБ) і Всесвітньою організацією охорони здоров'я (ВОО3) додано ще громадське здоров'я та природне середовище [8].

Поняття епідеміологічного нагляду: «систематичний та безперервно діючий процес виявлення, збору, складання та аналізу, тлумачення, поширення даних медико-санітарного призначення про стан здоров'я, благополуччя населення і показники середовища життєдіяльності, який здійснюється для оцінки і прийняття відповідних заходів у сорері громадського здоров'я» взяте із симбіозу двох нормативних актів.

Закон України «Про захист населення від інфекційних хвороб» говорить, що облік інфекційних хвороб ґрунтується на системі обов'язкової реєстрації кожного їх випадку незалежно від місця і обставин виявлення та оперативного (екстреного) повідомлення про нього закладів охорони здоров'я, визначених центральним органом виконавчої влади, що забезпечує формування державної політики у сорері охорони здоров'я для здійснення протиепідемічних заходів [5].

Наказ МО3 України «Про затвердження Порядку ведення обліку, звітності та епідеміологічного нагляду (спостереження) за інфекційними хворобами та Переліку інфекційних хвороб, що підлягають реєстрації», який не погоджений Державною регуляторною службою України як такий, що не відповідає ч. 2 ст. 19 Конституції України і дає більш близьке трактування до пропонованого: «епідеміологічний нагляд (спостереження) - систематичний та безперервно діючий збір, облік, складання та аналіз, тлумачення, поширення даних медико-санітарного призначення, епідемічного благополуччя населення і показників середовища життєдіяльності для оцінки і прийняття необхідних відповідних заходів в сорері громадського здоров'я» [4].

Рівень захворюваності та поширеності хвороб населення на певній території у визначений час даний законопроєкт визначає як «епідемічний стан», хоч існує термін «епідеміологія», який означає постійне існування на якій-небудь території певного, частіше всього, інфекційного захворювання, який звучить як «ендемія» (грец. en - «в»/«в межах» + demos - «люди») в популя- 
ції, коли ця хвороба постійно підтримується в цій популяції без потреби в зовнішніх джерелах [1].

Визначення календаря профрілактичних щеплень майже повністю скопійоване із Закону України «Про захист населення від інфекційних хвороб»: «календар профрілактичних щеплень (далі - календар щеплень) - нормативно-правовий акт центрального органу виконавчої влади, що забезпечує фрормування державної політики у сорері охорони здоров'я, яким встановлюються перелік обов'язкових профілактичних щеплень та оптимальні строки їх проведення» [5]. Відмінність полягає в тому, що після фррази «забезпечує фрормування» добавлено слово «та реалізує» державну політику в сорері охорони здоров'я. Така зміна змінює зміст самої фрункції календаря, який апріорі не може нічого реалізовувати, оскільки є неживим об'єктом, а не суб'єктом і являє собою простий перелік часових нормативів проведення щеплень. Реалізує державну політику вакцинації як запобігання певних захворювань первинна ланка медичної допомоги - педіатри та сімейні лікарі.

Невелика відмінність у визначенні контактних осіб у законопроєкті та Законі України «Про захист населення від інфекційних хвороб»: в обидвох варіантах це - «особи, які перебували в контакті $з$ джерелом інорекції, внаслідок чого вони...» в першому випадку «несуть ризик поширення інфрекційних хвороб», а в другому: «вважаються зараженими інфекційною хворобою» $[3,5]$.

У даному законопроєкті вводиться нова структура - уповноважений орган у сфері громадського здоров'я - «центральний орган виконавчої влади, що реалізує державну політику в сорері громадського здоров'я та санітарно-епідемічного благополуччя, у тому числі щодо організації та здійснення державного контролю, в порядку визначеному законом, за дотриманням вимог санітарного законодавства у сорерах господарської діяльності, які можуть становити ризик для санітарно-епідемічного благополуччя» [3]. У цьому законопроєкті не чітко визначено місце даного органу у виконавчій структурі влади, а отже унеможливлює його співфункціонування ні в плані розподілу праці, ні в плані фрінансування.

Генеральна асамблея ООН з профрілактики неінфекційних захворювань та боротьби з ними у 2011 р. прийняла документ, який чітко окреслив важливість розв'язання проблеми неінфекційних захворювань для розвитку людства - Політичну декларацію, яка визначила, що таке «неінфрекційні захворювання» [2]. До них віднесли тривалі та, як правило, повільно прогресуючі неінфекційні або хронічні захворювання - ті, що не передаються від людини людині. Існують основні чотири типи неінфекційних захворювань: серцево-судинні (інфраркт та інсульт), рак, хронічні респіра- торні захворювання (хронічне обструктивне захворювання легень і астма) та діабет. Отруєння до них не належать, як і результати небезпечних факторів середовища життєдіяльності біологічних, фрізичних, хімічних чи соціальних. Тому визначення поняття «масові неінфекційні хвороби (отруєння) - масові хвороби, виникнення яких зумовлено впливом біологічних, фрізичних, хімічних чи соціальних фракторів середовища життєдіяльності, у тому числі об'єктів господарської та інших видів діяльності, товарів, робіт, послуг» вважаємо некоректним. Тим більше, що $€$ визначення просто неінфекційних хвороб як «хронічні розлади здоров'я, виникнення яких зумовлено комбінованим впливом фракторів середовища життєдіяльності людини та генетичних фрізіологічних чи поведінкових чинників».

Варто звернути увагу на ч. 3 ст. 2 Закону України «Про систему громадського здоров'я», де йдеться про те, що положення цього Закону не поширюються на харчові продукти, крім харчових продуктів, щодо яких проводяться санітарно-епідеміологічні розслідування захворювань, спричинених інфекційними хворобами, масовими неінфекційними захворюваннями, отруєннями та радіаційним ураженням людей, а також випадків, прямо передбачених цим Законом. Мало втішає ситуація, коли інтерес наглядових органів до безпеки харчових продуктів проявляється постфрактум, коли уже є наявна нанесена ними шкода здоров'ю. 3 позицій профрілактики і беручи до уваги те, що власне харчові продукти є постійно вживаним фрактором довкілля, то нагляд за ними мав би бути постійним і багаторівневим, а не епізодичним і вибірковим.

Позитивним $є$ акцент на реєстрації введення в обіг, застосування пестицидів і агрохімікатів, дезінфікуючих засобів, консервантів, інших хімічних речовин 3 біоцидними властивостями відповідно до закону. Сьогодні доволі вільне поширення даних речовин призводить до численних проявів шкоди як довкіллю, так і здоров'ю людини. Масова загибель бджіл, зменшення чисельності корисних птахів, видозміна дикоростучих трав тощо свідчать про виражену небезпеку неконтрольованого використання вищезгаданих речовин.

Найбільше суперечок і побоювань викликає стаття 7 «Повноваження Кабінету Міністрів України», де йдеться про те, що Кабінет Міністрів України: «приймає рішення про проведення додаткових обов'язкових профрілактичних щеплень населення за епідемічними показаннями при загрозі епідемії інфекційної хвороби на території України». Провокує до непокори слово «обов'язково» [3]. Люди це слово сприймають як синонім насильства, звідси і така реакція, яка часто не є оправданою. До сьогодні в Україні обов'язковими були щеплення, передбачені ч. 1 
ст. 27 Закону України «Про забезпечення санітарного та епідемічного благополуччя населення» [7] та статті 12 Закону України «Про захист населення від інфекційних хвороб», проти туберкульозу, поліомієліту, дифтерії, кашлюку, правця та кору [5]. Щеплення проти інших захворювань мали бажаний, але добровільний характер. Водночас, якщо на даній території виникло небезпечне заразне захворювання - це становить загрозу зараження багатьох людей і тоді щеплення стають обов'язковими з усіма наслідками. І тут потрібно відзначити, що на сьогодні, враховуючи ліквідацію CEC, яка мала такі повноваження, реалізувати виконання такої дії $€$ проблематичним. Насильно вакцинувати людей ніхто не наважиться, але обмежити невакцинованих у певних діях цілком можливо. Європейський суд 3 прав людини (ЄСПЛ) більше схиляється до виправдання обов'язкової вакцинації перед правом вибору людини.

щодо позиції, що Кабінет Міністрів України «визначає критерії, за якими оцінюється ступінь ризику від провадження господарської діяльності у сорері санітарно-епідемічного благополуччя та визначається періодичність здійснення планових заходів державного нагляду (контролю) органами державного нагляду (контролю) за дотриманням вимог санітарного законодавства у відповідній сорері», то звернувшись до статті 20 Закону України «Про Кабінет Міністрів України», фрункція Кабінету Міністрів України полягає у тому, що він «забезпечує проведення державної політики у сорерах охорони здоров'я, санітарно-епідемічного благополуччя, охорони материнства та дитинства, освіти, фрізичної культури і доступність для громадян послуг медичних, освітніх та фрізкультурно-оздоровчих закладів», а критерії визначати може профільний орган і подавати на затвердження Кабінету Міністрів України [6].

Частина 2 статті 13 законопроєкту «Про систему громадського здоров'я», щодо обов'язків підприємств, установ і організацій у сорері санітарно-епідеміологічного благополуччя, також взята зі статті 7 Закону України «Про забезпечення санітарного та епідемічного благополуччя населення» [7].

У даному тексті $€$ два насторожуючі моменти. Перший, коли пропонується «усувати за поданням посадових осіб уповноваженого органу в сорері громадського здоров'я, органу державного нагляду (контролю) за дотриманням вимог санітарного законодавства у відповідній сорері від роботи, навчання, відвідування закладів освіти осіб, які є носіями збудників інфекційних хвороб, хворих на небезпечні для оточуючих інфекційні хвороби, або осіб, які були в контакті 3 такими хворими, з виплатою у встановленому законодавством порядку допомоги з соціального страхування» [3]. Остання позиція не може бути виконана, оскільки не відповідає принципам соціального страхування, зокрема принципу цільового використання коштів соціального страхування, а також потребуватиме додаткових коштів з бюджету Фонду соціального страхування України, джерела покриття яких відсутні. Також не чітко прописано який вид допомоги із соціального страхування пропонується здійснювати. Другий також достатньо проблематичний щодо усунення від навчання та роботи осіб, які ухиляються від обов'язкового медичного огляду або щеплення проти інфекційних хвороб, згідно із законодавством. Якраз згідно із законодавством такий крок зробити буде досить складно. Необхідно дотримуватися балансу між правами дитини на освіту та правами інших дітей щодо права на безпечне середовище.

Відповідно до чинного законодавства, зокрема Закону України «Про захист населення від інфекційних хвороб» [5], повнолітні особи дають таку згоду на профілактичні щеплення особисто. Щодо щеплення осіб, які не досягли п'ятнадцятирічного віку, згода надається їх батьками або іншими законними представниками. Для щеплення осіб віком від 15 до 18 років згоду необхідно отримати не тільки у них, але в одного з батьків (представників). І вони ж, згідно з даним документом, мають право на відмову від щеплень.

Знову ж необхідно закцентувати на тому, що весь ажіотаж навколо цих питань виникає через ряд недопрацювань в плані необізнаності громадян щодо питань вакцинації. Страх виникає через незнання. Найбільше людей лякає ймовірність виникнення ускладнень після вакцинації, побічні дії вакцин. І цей страх значно перевищує страх перед ризиком захворювань, що і створює масову відмову від вакцинації в Україні. А ще ситуацію ускладнює поширення антивакцинальної кампанії в засобах масової інформації та майже повна відсутність альтернативної спростовної пропаганди.

Дещо сумнівним для виконання видається позиція, де суб'єкти господарювання та громадяни забезпечують проведення профрілактичних дезінфекційних заходів у житлових, виробничих та інших приміщеннях (будівлях) і на земельних ділянках, що належать їм на праві власності чи надані в користування, здійснюють інші заходи з метою недопущення розмноження гризунів і комах у приміщеннях (будівлях), на земельних ділянках. Проблемним $\epsilon$ навіть дотримання цих вимог $\mathrm{y}$ житлових приміщеннях. Прикладом є заселення житла багатоповерхівок тарганами, і всім відомо, наскільки складно їх позбутися, навіть вживаючи локальних заходів, і наскільки важко це організувати тотально у всьому будинку. А якщо $є$ квартира з неблагополучними жильцями, то і поготів там будуть не лише таргани, а ці люди у влас- 
не житло відмовляються, на правах власності, впускати будь-кого. А позиція щодо виведення гризунів і комах на земельних ділянках, то без особливих коментарів, зрозуміла нереальність такого процесу. Цього року навіть посів озимих відклали через масове розмноження гризунів. Тому, щоб були виконані такі, безперечно хороші вимоги, насамперед мають бути налагоджені всі можливості їх виконання (від матеріальних, фізичних до фрінансових), а вже тоді відповідальність за їх невиконання. В іншому випадку це залишиться лише добрим наміром.

Необхідно також у черговий раз наголосити, що як і в інших законах, так і в цьому законопроєкті теж акцентується, що лише в межах програми державних фрінансових гарантій медичного обслуговування населення (а це не обов'язково в повному обсязі) особи, які хворіють на інфекційні хвороби чи є бактеріоносіями, мають право на повну оплату за рахунок коштів Державного бюджету України необхідних їм медичних послуг та лікарських засобів, пов'язаних із лікуванням інфекційної хвороби. До такого підходу громадяни повинні бути готові, щоб не виникало потім гірких розчарувань і нарікань на лікарів, медицину та державу в цілому.

У визначеннях даного законопроєкту термін «карантин» як «адміністративні та медико-санітарні заходи, що застосовуються для запобігання поширенню особливо небезпечних інфекційних хвороб» трактується аналогічно як і в Законі України «Про захист населення від інфекційних хвороб». Це визначення цілком адекватне і прийнятне за даних умов. Застереження викликає стаття 20 даного законопроєкту, яка стверджує, що карантин встановлюється та відміняється Кабінетом Міністрів України з подання центрального органу виконавчої влади, що забезпечує фрормування та реалізує державну політику в сорері охорони здоров'я за поданням Головного державного санітарного лікаря України. При неуточненні у законодавстві масштабів загрозливої події, при яких рішення про карантин прийматиме Кабінет Міністрів України, встановлення карантину в дитячому садочку з приводу випадку вітрянки потрібно буде запускати ланцюг протиепідемічних дій аж до участі Кабінету Міністрів України, або його не встановлювати. Тому в даному документі має бути чітко розмежовано функції виконавчої вертикалі для встановлення карантину при спалахах різних інфекційних захворювань від особливо небезпечних до дитячих інфекцій.

Стаття щодо залучення для тимчасового використання транспортних засобів, будівель, споруд, обладнання, інше майно підприємств, установ, організацій незалежно від фрорм власності, необхідне для здійснення профілактичних і протиепідемічних заходів, із наступним повним відшкодуванням у встановленому законом порядку його вартості або витрат, пов'язаних із його використанням, звучить дещо нереально через відсутність механізму такого залучення та механізму визначення та відшкодування і визначення джерел витрат на такі дії.

Викликає серйозну настороженість стаття 23 «Готовність та реагування на надзвичайні ситуації у сфрері громадського здоров'я» [3], коли у разі запровадження режиму надзвичайної ситуації, режиму надзвичайного стану або інших режимів, встановлених законодавством, на відповідних територіях для регулювання діяльності органів влади, суб'єктів господарювання та громадян тимчасово на термін дії відповідного режиму у разі неможливості забезпечення дотримання державних медико-санітарних нормативів та евакуації людей, замість державних медико-санітарних нормативів та правил можуть застосовуватися відповідні допустимі параметри впливу на організм людини фрізичних, хімічних та біологічних фракторів у надзвичайних ситуаціях.

Насамперед йдеться про якісь інші режими, встановлені абстрактним законодавством, коли застосовуватимуться замість медико-санітарних норм і правил якісь відповідні (до чого?) допустимі (ким?) параметри впливу (яких?) фракторів на організм людини! Мотивація таких дій теж досить дивна: «для регулювання діяльності органів влади, суб'єктів господарювання та громадян»!? Для прикладу, фрізичні фрактори - це температура, вологість, швидкість руху повітря, атмосферний тиск, шум, вібрації та інші види коливальної дії, неіонізуючі та іонізуючі випромінювання, кліматичні параметри тощо. Сам перелік потенційних можливостей такого впливу на організм людини вже викликає занепокоєння. Звичайно, що такі заяви, овіяні суцільною таємницею, виглядають досить загрозливо і провокують людей на спротив, що і відбулося з даним законопроєктом.

Наступний пункт даної статті підтверджує дані наміри такого впливу шляхом включення відповідних положень у рішення про введення режиму надзвичайної ситуації або режиму надзвичайного стану. Тобто декларується силовий механізм, що зазвичай в більшості випадків призводить до страху і спротиву.

Позитивним моментом є відстоювання даним законопроєктом обов'язкових профілактичних медичних оглядів працівників закладів освіти і дитячих закладів оздоровлення та відпочинку 3 метою виявлення хворих на інфекційні хвороби та бактеріоносіїв у порядку, встановленому центральним органом виконавчої влади, що забезпечує фрормування та реалізує державну політику в сорері охорони здоров'я.

Беззаперечним позитивом $€$ необхідність систематично проводити гігієнічне навчання та вихо- 
вання дітей та популяризувати здоровий спосіб життя та заходи профрілактики інфекційних хвороб серед батьків.

щодо заходів, спрямованих на збереження здоров'я і профрілактику хвороб, то попри добрі та благі наміри в законі не йдеться про джерела фрінансування цього напрямку.

Дивна і насторожуюча позиція щодо суб'єктів, які приймають рішення про проведення профрілактичних щеплень населення за епідемічними показаннями на відповідних територіях та об'єктах. Ці рішення, окрім керівників Ради міністрів Автономної Республіки Крим і місцевих органів виконавчої влади та центральних органів виконавчої влади, ще чомусь приймають керівники, що реалізують державну політику в сорерах оборони і військового будівництва, охорони громадського порядку, виконання кримінальних покарань, захисту державного кордону, Служби безпеки України у порядку, затвердженому центральним органом виконавчої влади, що забезпечує фрормування та реалізує державну політику в сорері охорони здоров'я. Останні ці рішення приймають додатково до перших чи паралельно, чи в окремих ситуаціях чи як? I, головне, для чого силові структури залучені до прийняття рішень щодо вакцинації?

Боротьба зі стійкістю до протимікробних препаратів регламентується в даному законопроєкті досить м'яко: через моніторинг, розвиток і вдосконалення методів та засобів діагностики, профрілактики та лікування в частині застосування про- тимікробних препаратів, консультування, освітню та інформаційно-просвітницьку діяльність щодо питань боротьби з протимікробною резистентністю, регулювання і реалізацію заходів щодо оптимального (раціонального) використання протимікробних препаратів у сфері охорони здоров'я, тваринництві, харчовій промисловості та інших визначених законодавством сорерах тощо. Це замість того, щоб запровадити заборону вільної реалізації антибіотиків як в медицині, так і у ветеринарії та використовувати їх виключно руками фрахівців.

Висновки
Даний законопроєкт орієнтований на стратегічний план розвитку громадського здоров'я, має бути консолідованим законом на кшталт Основ законодавства чи Кодексу. У ньому має бути чітко виписана виконавча структура, її місце у владних органах, співіснування 3 ними, фрункціональна підпорядкованість тощо. Декларативні стратегічні тези мають мати чітко визначене фрінансування зі зазначеними джерелами поступлень та співвідноситись із фінансовими можливостями.

Безперечно, що галузь громадського здоров'я потребує вагомого законодавчого підґрунтя, але воно має бути достатньо виважене, орієнтоване на інтереси як громади, так і окремого громадянина і не викликати настороги з боку населення.

Перспективи подальших досліджень полягають у вивченні фрунціональної співпраці різних органів виконавчої влади у галузі громадського здоров'я.

\section{Список літератури}

1. Ендемія [Електронний ресурс] // Енциклопедія сучасної України. - Режим доступу : http://esu.com.ua/search_ articles. php?id=17871.

2. Перетворення нашого світу: Порядок денний у галузі сталого розвитку на період до 2030 року : Резолюція Генеральної Асамблеї ООН, 2015. - 38 с.

3. Про забезпечення санітарного та епідемічного благополуччя населення : Закон України від 24 лютого 1994 р. № 4004-XII [Електронний ресурс] // Відомості Верховної Ради України. - 1994. - № 27. - Ст. 218. - Режим доступу : https://zakon.rada.gov.ua/laws/show/4004-12\#Text.

4. Про затвердження Порядку ведення обліку, звітності та епідеміологічного нагляду (спостереження) за інфекційними хворобами та Переліку інфекційних хвороб, що підлягають реєстрації : наказ МОЗ України [Електронний ресурс]. - Режим доступу : https://moz.gov.ua/article/public-discussions-archive/proekt-nakazu-ministerstva-ohoronizdorovja-ukraini-pro-zatverdzhennja-porjadku-vedennja-obliku-zvitnosti-ta-epidemiologichnogo-nagljadu-sposterezhennja-za-infekcijnimi-hvorobami-ta-pereliku-infekcijnih-hvorob-scho-pidljagajut-reestracii.

5. Про захист населення від інфекційних хвороб : Закон України від 06.04.2000 р. № 1645-ІІІ [Електронний ресурс]. - Режим доступу : https://zakon.rada.gov.ua/laws/show/1645-14\#Text.

6. Про Кабінет Міністрів України : Закон України [Електронний ресурс]. - Режим доступу : https://zakon.rada.gov.ua/ laws/show/794-18\#Text.

7. Про систему громадського здоров'я : Проект Закону України [Електронний ресурс]. - Режим доступу : http:// w1.c1.rada.gov.ua/pls/zweb2/webproc4_1?pf3511=70025.

8. Food safety and quality at FAO [Electronic resourse]. - Access mode : http://www.fao.org/food/food-safety-quality/ home-page/en/.

\section{References}

1. Entsyklopediia suchasnoi Ukrainy Endemiia [Encyclopedia of modern Ukraine Endemic]. Retrieved from: http://esu.com. ua/search_articles.php?id=17871 [in Ukrainian].

2. (2015). Peretvorennia nashoho svitu: Poriadok dennyi u haluzi staloho rozvytku na period do 2030 roku [Transforming our world: The 2030 Agenda for Sustainable Development]. Rezolyutsiya Heneral'noyi asambleyi OON - Resolution of the UN General Assembly [in Ukrainian]. 
3. (1994). Zakon Ukrainy «Pro zabezpechennia sanitarnoho ta epidemichnoho blahopoluchchia naselennia» [Law of Ukraine "On Ensuring Sanitary and Epidemic Welfare of the Population"]. Vidomosti Verkhovnoi Rady Ukrainy - Information of the Verkhovna Rada of Ukraine, 27, st.218). Retrieved from: https://zakon.rada.gov.ua/laws/show/4004-12\#Text [in Ukrainian]. 4. Nakaz MOZ Ukrainy «Pro zatverdzhennia Poriadku vedennia obliku, zvitnosti ta epidemiolohichnoho nahliadu (sposterezhennia) za infektsiinymy khvorobamy ta Pereliku infektsiinykh khvorob, shcho pidliahayut reiestratsii» [Order of the Ministry of Health of Ukraine "On approval of the Procedure for accounting, reporting and epidemiological surveillance (surveillance) of infectious diseases and the List of infectious diseases subject to registration"]. Retrieved from: https:// moz.gov.ua/article/public-discussions-archive/proekt-nakazu-ministerstva-ohoroni-zdorovja-ukraini-pro-zatverdzhennjaporjadku-vedennja-obliku-zvitnosti-ta-epidemiologichnogo-nagljadu-sposterezhennja-za-infekcijnimi-hvorobami-tapereliku-infekcijnih-hvorob-scho-pidljagajut-reestracii [in Ukrainian].

5. (2000). Zakon Ukrainy «Pro zakhyst naselennya vid infektsiynykh khvorob» № 1645-III vid 06.04.2000 roku [Law of Ukraine "On protection of the population from infectious diseases"]. Retrieved from: https://zakon.rada.gov.ua/laws/ show/1645-14\#Text [in Ukrainian].

6. Zakon Ukrainy «Pro Kabinet Ministriv Ukrayiny» [Law of Ukraine "On the Cabinet of Ministers of Ukraine"]. Retrieved from: https://zakon.rada.gov.ua/laws/show/794-18\#Text [in Ukrainian].

7. Proiekt Zakonu Ukrainy «Pro systemu hromadskoho zdorovia» [Draft Law of Ukraine "On the Public Health System"]. Retrieved from: http://w1.c1.rada.gov.ua/pls/zweb2/webproc4_1?pf3511=70025 [in Ukrainian].

8. Food safety and quality at FAO. Retrieved from: http://www.fao.org/food/food-safety-quality/home-page/en/

\section{CURRENT ISSUES OF THE DRAFT OF LAW OF UKRAINE "ON THE PUBLIC HEALTH SYSTEM"}

O. N. Lytvynova, L. P. Zaporozhyan, K. Y. Yuriyiv

I. Horbachevsky Ternopil National Medical University, Ternopil, Ukraine

Purpose: to show the current issues of public health, proclaimed in the draft of Law of Ukraine "On Public Health" and the possibility of their implementation.

Materials and Methods. Using the method of system analysis, the study of the most pressing tasks of the public health system in this draft was conducted.

Results. This draft of Law, focused on a strategic plan for the development of public health, must be a consolidated law such as the Fundamentals of Legislation or the Code. It must clearly state the executive structure, its place in government, coexistence with them, functional subordination, and other.

This draft of Law introduces a new structure, an authorized organisation in the field of public health, which is as "the central executive body that implements state policy in the field of public health and sanitary and epidemiological well-being, including the organization and implementation state control, in the manner prescribed by law, for compliance with the requirements of sanitary legislation in the areas of economic activity, which may pose a risk to sanitary and epidemiological well-being". This draft of Law does not clearly define the place of this body in the executive structure of power, and therefore makes it impossible to co-operate either in terms of division of labor or in terms of funding.

Declarative strategic theses should have clearly defined funding with the indicated sources of income and be correlated with financial opportunities. The issue of vaccination today has signs of legal conflict and requires a balance between individual rights and community interests. Public health issues must be addressed by a consolidated community and concerted action by the executive branch. Health promotion and disease prevention should be a priority of public health policy.

Conclusions. There is no doubt that the public health branch needs a strong legislative basis, which must be sufficiently balanced, focused on the interests of both the community and the individual citizen, and does not cause alarm on the part of education.

KEY WORDS: public health; draft; vaccination; life safety.

Рукопис надійшов до редакції 10.09.2020 p.

\footnotetext{
Відомості про авторів:

Литвинова Ольга Несторівна - кандидат медичних наук, доцент касредри громадського здоров'я та управління охороною здоров'я Тернопільського національного медичного університету імені І. Я. Горбачевського МОЗ України; тел.: +38(0352) 52-72-33.

Запорожан Лариса Петрівна - кандидат географічних наук, доцент кафедри громадського здоров'я та управління охороною здоров'я Тернопільського національного медичного університету імені І. Я. Горбачевського МОЗ України; тел.: +38(0352) 52-72-33.

юріїв Катерина Євгенівна - кандидат медичних наук, доцент кафедри патологічної фрізіології Тернопільського національного медичного університету імені І. Я. Горбачевського МОЗ України; тел.: +38(0352) 43-12-62.
} 